Portland State University

PDXScholar

\title{
Upstream Predictors of the Need for Developmental Education among First-year Community College Students
}

\author{
Mathew C. Uretsky \\ Portland State University, muretsky@pdx.edu \\ Stacey L. Shipe \\ Binghamton University \\ Angela K. Henneberger \\ University of Maryland
}

Follow this and additional works at: https://pdxscholar.library.pdx.edu/socwork_fac

Part of the Social Work Commons

Let us know how access to this document benefits you.

\section{Citation Details}

Uretsky, M. C., Shipe, S. L., \& Henneberger, A. K. (2019). Upstream Predictors of the Need for Developmental Education among First-year Community College Students. Community College Journal of Research and Practice, 1-15.

This Post-Print is brought to you for free and open access. It has been accepted for inclusion in School of Social Work Faculty Publications and Presentations by an authorized administrator of PDXScholar. Please contact us if we can make this document more accessible: pdxscholar@pdx.edu. 
Upstream Predictors of the Need for Developmental Education among First-year Community College Students

\author{
Mathew C. Uretsky ${ }^{1}$, Stacey L. Shipe ${ }^{2}$, and Angela K. Henneberger ${ }^{3}$ \\ ${ }^{1}$ Portland State University \\ ${ }^{2}$ Binghamton University \\ ${ }^{3}$ University of Maryland School of Social Work
}

\title{
Citation:
}

Uretsky, M.C., Shipe, S.L., \& Henneberger, A.K. (2019). Upstream predictors of the need for developmental education among first-year community college students. Community College Journal of Research and Practice, 1-15. doi: 10.1080/10668926.2019.1655501

Acknowledgement: This research was supported by the Maryland Longitudinal Data System (MLDS) Center. We are grateful for the assistance provided by the MLDS Center. Prior versions of this manuscript were published by the MLDS Center and findings were presented to multiple local and statewide stakeholder audiences. We appreciate the feedback received from the MLDS Center and its stakeholder partners. Additionally, we thank the panelists and attendees at multiple academic conferences and the anonymous reviewers of the current journal for helpful feedback on this manuscript. All opinions are the authors' and do not represent the opinion of the MLDS Center or its partner agencies. 


\begin{abstract}
Objective/Research Question. How do student- and school-level factors measured in the final year of high school contribute to the odds of a student being assessed to need remediation in Math during the students' first community college enrollment?

Methods. The present study draws on five years of linked secondary and post-secondary administrative records and includes the academic records for 18,814 students attending 228 high schools across 24 jurisdictions in Maryland. We used a series of multilevel models (MLM) to address the research question.

Results. Using MLM, we identified both student and school-level factors, drawn from the final year of high school, which relate to the odds of needing math remediation in their first year of community college. Of note, student-level academic performance in high school had a larger influence on the odds that a student would need remedial education than socio-demographic factors. In addition, receiving English language learner services and graduating from high school in the fifth-year functioned as protective factors linked to a reduced likelihood of needing math remediation.

Conclusions/ Contributions. Community colleges are functionally dependent upon secondary schools to prepare the student body for college level coursework. As such, preventing the need for remediation among community college students will not be resolved within institutional siloes and will most probably require some degree of inter-system collaboration. The findings from the current study presents opportunities for early identification and suggest possible targets for intervention intended to reduce the likelihood that high-risk students will need remedial coursework when they arrive at community college.
\end{abstract}


Each fall, as incoming students begin matriculating at college campuses across the US, many discover that their previous educational experiences have not prepared them for collegelevel coursework. Postsecondary institutions have addressed the widespread skill discrepancies observed among US high school graduates by requiring under-prepared students to complete developmental courses — usually in math, reading, or English—before moving on to college-level work. Although estimates vary, one third to a half of all undergraduates place into at least one developmental course during their college career (Chen, 2016; Radford \& Horn, 2012). These numbers suggest a substantial mismatch between the expectations for earning a high school diploma and the minimum acceptable standards for post-secondary readiness.

Public community colleges deliver the bulk of developmental education (Chen, 2016; Clotfelter, Ladd, Muschkin, \& Vigdor, 2015). Estimates suggest that more than two-thirds of community college students need at least one developmental course during their postsecondary career and more than half require two or more; numbers that are 20 and 30 points higher than students at 4-year institutions respectively (Chen, 2016; Radford \& Horn, 2012). The need for developmental education is most pronounced in math, with nearly two thirds of community college students needing developmental coursework in the subject compared to just over a quarter of students needing developmental coursework in English or reading (Baily, Jeong, \& Cho, 2010; Chen, 2016).

A confluence of factors have placed the responsibility for providing the bulk of developmental coursework on public community college systems. The open enrollment approach that most community colleges offer leads them to serve a more diverse student body with higher levels of academic need. In addition, community colleges traditionally offer more developmental courses than 4-year colleges at a lower cost (Buddenhagen, 2014). Moreover, some states have 
instituted policies that prohibit 4-year colleges from offering developmental courses (Bettinger \& Long, 2009; Scott-Clayton \& Rodriguez, 2012).

Preventing the need for developmental coursework and determining the best way to serve the population of students who eventually need developmental coursework hinges on accurately identifying early predictors for the targeting of prevention and intervention services. Yet, accurately pinpointing such factors has proven difficult (Barnett, Bergman, Kopko, Reddy, Belfield, Roy, \& Cullinan, 2018; Barnett \& Reddy, 2017). Despite the challenges, research findings can provide practitioners with guidance about which students to target and the best mechanisms to focus on for early intervention. For example, if sociodemographic predictors are identified as the most relevant factors, practitioners may want to develop programming for students based on demographic characteristics. However, if factors relating to academic achievement are identified as the most salient predictors, practitioners could use factors such as GPA or standardized test scores to identify students for intervention (Barnett \& Reddy, 2017). Another possibility is that high school level factors could be identified as the most important predictors, in which case, practitioners may want to focus on whole school reform or schoolwide intervention strategies (Barnett, Chavarín, \& Griffin, 2018; Barnett, Fay, Pheatt, \& Trimble, 2016). The current study will contribute to this literature by using statewide linked longitudinal secondary and post-secondary data to examine the demographic and academic predictors at the student and school-levels that relate to the need for developmental coursework in Math at Maryland community colleges.

\section{Background}

Students who enter postsecondary education without the requisite skills to complete college level coursework experience a number of undesirable outcomes that ultimately impact 
the student, their families, and the communities in which they reside. Two-thirds of college students who need developmental coursework do not earn a diploma or technical certificate and fewer than 1 in 10 students who take developmental coursework transfer to a 4-year institution (Clotfelter et al., 2015; Collins \& Couturier, 2008; Horn \& Berger, 2004). Students that take developmental courses rarely advance to college-level credit bearing courses in the remediated subject; this is particularly so if the student must take more than one developmental course (Bailey, Jaggars, \& Jenkins, 2015) The lack of successful transfer is particularly evident among students assessed to need developmental math coursework with approximately $33 \%$ of students taking developmental math moving to college-level math (Bailey, Jeong, \& Cho, 2010; Melguizo, Bos, \& Prather, 2011).

\section{Predictors of the need for developmental coursework}

The education production function theory considers the individual student and structural inputs that combine to produce educational outputs such as high school graduation and postsecondary enrollment (Lamdin, 1996). For example, when there is a focus on increasing language acquisition for non-English speaking students, a student's chance of college success increases (Lucas, Henze, \& Donato, 1990) although some research suggests these courses occur prior to high school to optimize college success (Callahan, Wilkinson, \& Muller, 2010). Similarly, the conceptual model of high school performance describes the individual and institutional factors that are theorized to drive academic development among secondary school students (Rumberger, 2011). For example, schools that focus on factors that are not necessarily academic, such as "grit" and self-awareness are known to increase graduation rates (Duckworth \& Quinn, 2009; Hein, Smerdon, \& Sambolt, 2013). Additionally, when a school focuses on racial and ethnic disproportionality in special education and attempts to ameliorate these 
inequities through targeted approaches like Response to Intervention (RTI; Fuchs \& Fuchs, 2006) or functional assessments (Sugai, Lewis-Palmer, \& Hagan-Burke, 2000) the number of minority students in special education decrease and overall success in secondary school increases.

The literature describing causes and correlates of the need for developmental education has, for the most part, concentrated on student's high school experiences and sociodemographic factors (Bettinger \& Long, 2009; Chen, 2016). The studies examining the role of high school experiences have mostly focused on student location (e.g., neighborhood), the school environment, and the types of courses offered (Scott-Clayton \& Rodriguez, 2012). Students from low-income neighborhoods who attend poorly resourced high schools are more likely to need additional coursework upon entering college (Vance, 2017). Underfunded public high schools are often overcrowded and employ inexperienced teachers who tend to turnover at higher rates than teachers at better-resourced schools. In addition, such schools tend to lack the resources to offer advanced courses in science, technology, engineering, and mathematics (STEM; Atchison, Baker, Boyle, Levin, \& Manshi, 2017). This is not meant to imply that high school teachers are ill willed or uninterested in the outcomes of underperforming students. To the contrary, a recent qualitative article by Williams, Thompkins, and Rogers (2018) found that teachers expressed a desire to participate in the discussion surrounding developmental education. The teachers articulated a belief that improvements in intersystem collaboration and curricular alignment (especially in Math) would lead to fewer students needing developmental education when they arrived at community college.

Sociodemographic research has consistently found students who identify as either lower income, minority, first-generation, or English as a second language are more likely to need 
developmental coursework (Attewell, Lavin, Domina, \& Levey, 2006; Bremer et al., 2013; Clotfelter et al., 2015). The disparity is particularly pronounced among Black and Latino students even after controlling for academic history and social background (Attewell et al. 2006; Chen, 2016; Gandara, Alvarado, Driscoll, \& Orfield, 2012). A disproportionate number of first generation Americans and English as Second Language students are placed in developmental courses (Engle \& Tinto, 2008; Ward, Siegel, \& Davenport, 2012). In a recent study, Flores \& Drake, (2014) found that Latino students designated as English Language Learners (ELL) were more likely to need developmental coursework in reading and writing, but less likely to need developmental coursework in Math than non-ELL. In the Asian student population, ELL students were more likely to need developmental coursework in reading, but not in writing or math (Flores \& Drake, 2014).

Students with disabilities are more likely to enroll in developmental education classes in college compared to their non-disabled counterparts (Neubert \& Redd, 2008; Thoma et al., 2011). In 2010, the US Department of Education recognized the need to adequately prepare special education students during their transition to college and encouraged the development of multiple pilot projects (Folk, Yamamoto, \& Stodden, 2012; Plotner \& Marshall, 2015). Unfortunately, due to small samples, which are common among such pilot efforts, the studies did not have sufficient sample size to observe differences by disability type.

In recent years, some high schools have begun to offer "transition courses" to students who are at risk of encountering difficulties making the transition from secondary to postsecondary. These courses are usually developed and delivered in partnership with secondary and post-secondary educators and designed to improve student readiness for the rigors of college (Barnett, Chavarín, \& Griffin, 2018; Barnett, Fay, Pheatt, \& Trimble, 2016). At risk status is 
commonly determined using $11^{\text {th }}$ grade assessment scores. Students who are identified as needing support are offered transitional coursework, typically in math or English, during their senior year with the goal of adequately preparing the student to take for credit college-level courses upon their entry to a post-secondary institution (Barnett et al., 2016).

Despite the promise of early interventions, there is no universal definition of college readiness. As such, there are widespread differences in what is offered under the auspice of a transitional course offer, particularly as it relates to the curricular focus of the course (i.e., Common Core standards, college placement tests such as the SAT/ACT, etc.). Moreover, the research findings describing the effectiveness of transitional courses have been mixed. For example, some findings have indicated that math transition courses were less effective than other types of math content (Barnett et al., 2016). Other studies have reported that the majority of students who took a math transition course subsequently enrolled in college level classes, although this did not guarantee success in those classes (Kane, Boatman, Kozakowski, Bennett, Hitch, \& Weisenfeld, 2018).

In general, the research on the predictors of the need for college-level developmental coursework can be difficult to interpret due to variations in the tools used to assess student need. For example, Chen (2016) found an association between student need of developmental coursework and lower scores on a composite measure of high school grade point average (GPA), math courses taken, and college admissions test scores. Similarly, Bettinger and Long (2009) found students who had lower ACT scores and high school GPAs were more likely to be placed in developmental math and English. Scott-Clayton, Crosta and Belfield (2014) attempted to improve upon this by developing predictive models for colleges that combined high school transcripts, test scores, and college grades. However, the resulting logic is at times circular as 
the predictive variables from such studies - e.g. ACT scores, math course taking history, and college placements scores — are used by many post-secondary institutions as tools for determining student need for developmental coursework. Even in the Scott-Clayton et al. (2014) study, the researchers concluded that accurately predicting those needing developmental education is very difficult. In addition, even when common assessment tools are used across institutions, many colleges set unique cutoff scores to determine the need for developmental coursework, which further complicates any effort to compare predictors and outcomes across multiple sites (Bettinger \& Long, 2009).

Our current understanding of the predictors of developmental coursework is limited in several ways. First, in many studies, the sample of students who needed developmental coursework is typically small and limited to a single college or high school district. This can limit the variation on important factors and limit the ability to examine relatively small, but important, subgroups of students. For example, prior research on the effects of a fifth year of high school on the need for developmental coursework is limited because small sample sizes have prevented the examination of this student subgroup (Jimerson \& Ferguson, 2007; Jimerson, Anderson, \& Whipple, 2002).

The current study uses statewide population-level data to enable examination of subgroups of students who have typically been under-represented in prior research (e.g., special education students, fifth year graduates). Second, the current study addresses the limitations from previous research by drawing the study sample from community colleges in Maryland that use a single placement instrument-Accuplacer-with a common cutoff score (Halbach, 2015). The institution of a hard cutoff score to identify the need for developmental coursework by community colleges in Maryland removes test-specific between-school variation in placement 
practices which can present difficulties in comparing student outcomes across multiple institutions. Third, we look at student experiences in the year following high school graduation in order to limit bias that may result from the wide variations in the age and experiences of the students who are assessed to need developmental coursework. The current study will examine the upstream student- and school-level predictors of the need for developmental coursework among community college students through the following research question:

To what extent do student- and school-level factors relate to the odds of a student being assessed to need developmental coursework in Math in the students' first community college enrollment?

\section{Method}

\section{Sample and Data Source}

Data for this study were from the Maryland Longitudinal Data System (MLDS), Maryland's state repository for linked student and workforce data. This study draws on five years of administrative records and includes the academic records for 18,814 students attending 228 high schools across 24 jurisdictions in Maryland. In addition, the dataset includes linked college enrollment and assessment data across the community colleges attended by the students in the dataset. Student- and school-level descriptive statistics for the sample are presented in Tables 1 and 2 respectively.

insert table 1 about here -insert table 2 about here

There was missing data for 355 students across all variables (Gender, GPA 3.0 or above, Foreign Language Indicator, Math Indicator, Science Indicator, Weeks Attended). Cases with missing data were deleted listwise resulting in a final sample of 18,459 . Students with missing 
data were assessed to need remediation at a lower rate (37\%) than students with no missing data $(52 \%)$. This difference was statistically significant $\left(\chi_{(1)}^{2}=37.14, p<.0001\right)$.

Table 3 provides a summary of the need for developmental coursework within the study sample. Nearly 3 out of 5 Maryland high school graduates were assessed to need developmental coursework in at least one subject in their first semester of community college. Just over half of students needed developmental coursework in math, $28 \%$ needed developmental coursework in English, and one quarter of the students needed developmental coursework in Reading. Among the students assessed to need developmental coursework, more than 9 out of 10 students needed developmental coursework in Math. About half of the students needed developmental coursework in English and more than two out of five needed developmental coursework in Reading.

-insert Table 3 about here

More than half (55\%) of students who needed developmental coursework qualified in more than one subject, and nearly a third qualified in all three subjects. Two out of five students who needed developmental coursework needed math only. Two percent needed Reading only and three percent of students needed English only.

\section{Inclusion Exclusion Criteria}

Students were included in the current study if they were (1) a Maryland public high school student who earned a regular high school diploma in the 2013-2014 academic year and (2) enrolled in one of the 24 Maryland Community Colleges in the 2014-2015 academic year. Although Maryland colleges offer developmental coursework at both two- and four-year institutions, the standards for placement in developmental coursework can vary across four-year Universities and Colleges. Community colleges in Maryland have adopted the Accuplacer test 
from the College Board as a common tool to identify the need for developmental education. In addition all Maryland community college use a standard placement cutoff score to indicate college readiness or the need for developmental coursework among their incoming students (Halbach, 2015). In order to improve homogeneity, the study sample was limited to students who enrolled in a community college in the year following their high school graduation.

\section{Measures}

The variables included in the current study were selected based on their relationships to the existing literature on academic development and high school completion. Specifically, we drew on two main sources. First, we were guided by the literature concerning the education production function which considers the individual and structural inputs that combine to produce educational outputs such as high school graduation, post-secondary enrollment, and participation in the labor force (Lamdin, 1996). Secondly, we were guided by Rumberger's (2011) Conceptual Model of High School Performance which describes the individual and institutional factors that are theorized to drive academic development among secondary school students.

Dependent variable. Developmental Math, is a dichotomous indicator describing whether a student was (vs. not) determined to need developmental coursework in math at a Maryland Community College in the 2014-2015 academic year.

Individual student characteristics. Variables that describe individual student characteristics fall into three broad categories: (1) demographic characteristics; (2) attendance and academic performance; and (3) placement characteristics. Demographic characteristics included gender (Female vs. Male), Ethnicity (Hispanic vs. not), and eligibility for the free and reduced lunch program (FARMs vs. not). A series of dummy variables were created to describe student race, including Black, Asian, and Other Race with White serving as the reference group. 
Attendance and academic performance included GPA 3.0, which is a dichotomous indicator describing whether a student had a high school GPA equal to or greater than 3.0 (vs. below 3.0), and the Foreign Language Indicator which is a dichotomous indicator describing whether a student had taken two or more foreign language classes with a grade of B of higher. The Math Indicator is a dichotomous indicator describing whether a student had taken two or more Math classes with a grade of B or higher. The Science Indicator is a dichotomous indicator describing whether a student had taken two or more science classes with a grade of B or higher. The school system collects data for these indicator variables at the time of high school completion in order to summarize a student's educational experience. To measure high school attendance five-day school week equivalents were calculated and summed to create an estimate of the total weeks attended during the 2013-2014 school year (Max = 36 weeks). Placement characteristics included receipt of special education services during high school (vs. not), participation in English language learner programming during high school (vs. not), and graduating as a fifthyear senior (vs. Four-year graduate).

School characteristics. School characteristics were calculated using data for all twelfthgrader students attending each high school in the 2013-2014 school year. All school-level parameters, other than attendance, were divided by 10 to improve interpretability of the results in relation to student-level factors (Kline, 2011).

\section{Analytic Approach}

We addressed the study's central research question using a multilevel generalized linear mixed modeling approach for hierarchical data with binary outcomes using the GLIMMIX module with a logit link for SAS 9.3 (Dai, Li \& Rocke, 2006). All applicable statistical assumptions of multilevel logit models were assessed. The assumption of non-multicollinearity 
was assessed for model parameters using Pearson's product-moment correlations run between continuous independent variables with a cutoff of .8 as suggested by Studenmund (2014).

First, we ran a two-level unconditional logit model for dichotomous outcomes (Hox, 2002). We applied a random intercept modeling approach to account for differences in the outcome variables across schools. Next, we ran a series of multilevel logit models, which included individual student- and school-level predictors. We used random effects to model the intercepts and fixed effects for the independent variables. All continuous covariates were grandmean centered (Algina \& Swaminathan, 2011; Enders \& Tofighi, 2007). In order to account for the nesting of schools within jurisdictions (districts), dummy variables for each of the 24 jurisdictions in Maryland were entered into the model with one omitted at random (Huang, 2016). Improvements in model fit associated with including additional model parameters were evaluated in sequential models using a log-likelihood difference test (Ene et al., 2015).

\section{Results}

The z-test for the covariance parameters $(z=8.00, \mathrm{p}<.0001)$ indicated a statistically significant between-school variation in the need for math developmental coursework (see Table 4), providing justification for the use of MLM techniques (Hox, 2002).

-insert Table 4 about here-

Model fit. We used the log-likelihood difference test to assess improvements in model fit resulting from the addition of variables in sequential models (Ene et al., 2015). Including student-level predictors in the model resulted in improved model fit relative to the null model $\left(\chi^{2}\right.$ $(37)=2820.25, p<.0001)$. We entered the level-2 variables in two sets, in order to separately assess the ability of school-level concentrations of (1) student demographic and behavioral characteristics, and (2) indicators of academic achievement to explain between-school 
differences in student outcomes. The results indicated a significant improvement in model fit after the inclusion of the first set of level-2 variables (percentage FARMS, percentage English Language Learner, percentage Fifth-Year Graduate, Mean Weeks Attended; $\chi^{2}(4)=21.07, p<$ .0001). The inclusion of the second set of school-level variables (percent GPA 3.0 or Above, percent Math Indicator, percent Foreign Language, Indicator, percent Science Indicator) did not significantly improve the models fit to the data $\left(\chi^{2}(4)=5.62, p=.229\right)$. The non-significant result indicates that the second set of school-level variables did not explain any additional variance in math developmental coursework and were therefore excluded from the final model (see Table 4).

Student-level factors. Asian students $(\mathrm{OR}=.844, p=.024)$, English Language learners $(\mathrm{OR}=.395, p<.0001)$ and fifth-year graduates $(\mathrm{OR}=.664, p=.001)$ were less likely to need developmental coursework in Math. Students who had a GPA above $3.0(\mathrm{OR}=.612, p<.0001)$ and students who earned a grade of 'B' or better in two or more Foreign Language ( $\mathrm{OR}=.764, p$ $<.0001)$, Math $(\mathrm{OR}=.423, p<.0001)$, or Science $(\mathrm{OR}=.582, p<.0001)$ courses were also less likely to need developmental coursework in Math. Being female $(\mathrm{OR}=1.468, p<.0001)$, Hispanic $(\mathrm{OR}=1.281, p<.0001)$, eligible for FARMs $(\mathrm{OR}=1.086, p<.035)$, and being identified as requiring Special Education services $(\mathrm{OR}=1.252, p<.0001)$ were related to increased odds of needing developmental coursework in Math. There was no significant relationship between being Black ( $p=.169)$, Other Race $(p=.172)$, or the number of weeks attended in the final year of high school $(p=.780)$ with the odds of needing developmental coursework in math controlling for other variables in the model.

\section{School-level factors and the odds of needing developmental coursework in Math.}

Students who attended a high school with a higher percentage of students who were FARMs eligible $(\mathrm{OR}=1.085, p<.001)$, had increased odds of being assessed to need developmental 
coursework in Math at Community College. Students who attended a high school with a higher percentage of fifth-year graduates $(\mathrm{OR}=.930, p=.027)$ had decreased odds of being assessed to need developmental coursework in Math at Community College. There was no significant relationship between the percent of English Language Learners in a school $(p=.309)$ or Mean Weeks Attended $(p=.989)$ with the odds of needing developmental coursework in math.

\section{Discussion}

The present study examined the student and high school level predictors associated with needing developmental coursework in Maryland community colleges. Consistent with the education production function (Lamdin, 1996) and Rumberger's (2011) conceptual model of high school performance, we found that several student sociodemographic and academic characteristics (i.e., female, eligibility for FARMs, special education services, ELL services, and fifth year in high school) were related to need for developmental coursework. Also consistent with prior research on high school performance, academic factors were related more strongly to the need for developmental coursework than sociodemographic (Rumberger, 2011). In addition, as suggested by Rumberger, high school level factors were related to the need for developmental coursework. These findings have specific implications for developing and targeting interventions to prevent the need for developmental coursework in community college.

\section{Predictors of the need for developmental coursework in math}

Among the student level predictors, being female, Hispanic, FARMs eligible, and receiving special education services related to increased odds of needing math developmental coursework. In a comparative study on students taking developmental courses in community colleges, Chen (2016) found that females, Hispanic, and lower income students enrolled in more developmental courses. In the current study, female students had $48 \%$ higher odds of needing 
developmental coursework in math compared to males. This could be related to the well documented gender disparities in STEM education and the persistent narrative that males are better in math than females, resulting in females overwhelmingly enrolling in fewer math and science classes (Else-Quest, Hyde, \& Linn, 2010; Lindberg, Hyde, Peterson, \& Linn, 2010). In the current study, Hispanic and FARMs eligible students had 33\% and 9\% higher odds of needing developmental coursework compared to non-Hispanic students and non-FARMs eligible students respectively. Research has suggested that the relatively higher need for developmental coursework observed among Hispanic and lower income students is driven by a lack of educational opportunities, characterized by the concentration of vulnerable and underserved student groups into underfunded secondary schools where access to high quality education is compromised (Berg, 2016; Mejia, Rodriguez, \& Johnson, 2016).

It is important to note that being Black or Other race was not significantly related to the need for developmental education in this sample after controlling for the other variables in the model. Asian students were less likely to need developmental math compared to white students. This is similar to, but more generalized than, the finding by Flores \& Drake (2014) that Asian ELL students were less likely to need developmental math. In addition, as found by Hodara (2015), we observed that student-level academic performance in high school (e.g. GPA and course taking) had a larger influence on the odds that a student would need developmental education than socio-demographic factors (e.g. race, ethnicity, FARMs).

There has been relatively sparse postsecondary research focused on students who received special education services in high school. This is an important gap in research knowledge given that nearly two-thirds of students with disabilities who enroll in college do so at community colleges (Horn, Peter, \& Rooney, 2002; Mamiseishvili \& Koch, 2011). Yet, few 
studies have populations large enough to examine the developmental coursework outcomes of special education involved students. Prior research indicates that a quarter of special education students do not persist past their first year and more than half do not return after their third year (Mamiseishvili \& Koch, 2012). The results of the current study indicated that students who received special education services in high school had higher odds of needing developmental coursework in math when compared to students who did not receive services (Ankeny \& Lehmann, 2010). Future research should examine the needs of special education students to determine the most appropriate interventions to help students succeed upon enrolling in community colleges.

The finding from the current study that students who received ELL services are less likely to need math developmental coursework concurs with findings from previous studies (Flores \& Drake, 2014). In addition, as other research has found, students in the current study with high academic achievement in high school were less likely to need developmental math courses (Attewell et al., 2006; Clotfelter, 2015). Although the finding that ELL students are less likely to need developmental coursework in math is not new, there are important policy and practice implications that may have relevance beyond the ELL population. The concept of the "Bilingual Brain" may provide some insight into why ELL services, which focus primarily on language acquisition, would have a complimentary relationship with math skills. The "Bilingual Brain” framework speaks to the cognitive benefits of bilingualism where bilingual individuals tend to outperform monolingual individuals in executive function and information selection tasks (Stocco et al., 2014). The framework is supported by the finding from the current study that students who received a grade of " $\mathrm{B}$ " or higher in two or more foreign language courses were less likely to need developmental coursework in math. Another possible explanation could be 
that the additional adult attention provided to ELL students around language support has corollary benefits in adjacent subjects, such as math.

In the current study sample, fifth-year graduates had lower odds of needing math developmental coursework in community college. To our knowledge, this is the first time that the relationship between length of time to high school graduation and need for developmental coursework has been explored. The finding that fifth-year graduates are less likely to need math developmental coursework compared to four-year high school graduates may indicate the utility of the additional adult support provided by an extra year of high school education. Prior research indicates the importance of non-parental adult support, particularly for under-represented students (Hurd \& Sellers, 2013; Hurd, Tan, \& Loeb, 2016; Hurd \& Zimmerman, 2014). It is possible that, for both students who graduate in the fifth-year and ELL students, the additional time with supportive adults is providing math benefits regardless of the primary intervention goals. Additional research would be required to determine if any causal pathway exists, but if true this would provide the rationale for a wide range of non-specific supportive interventions. In addition, these findings indicate the potential for preventative coursework or services to be provided in high school, such as the emerging efforts of transitional coursework (e.g. Barnett, Chavarín, \& Griffin, 2018).

Like the student-level factors, the significant school-level factors in this study had overlap with previous literature. Students who attended schools with more FARMs eligible students had higher odds of needing math developmental coursework in community college. This could be explained by research demonstrating that, typically schools have a difficult time meeting the needs of vulnerable students in educational environments where students with complex needs are concentrated together (Rothstein, 2015). 
We could not locate any studies that have considered the school-level effects for fifthyear graduation, ELL service use, or mean attendance. In the current study, students who attended schools with a higher percentage of fifth-year graduates were less likely to need math developmental coursework. This suggests that schools that have more experience serving fifthyear graduates are better at preparing all students for college level math providing a slightly more hopeful outlook. In contrast, students who attended schools with a higher percentage of FARMs eligible students were more likely to need math developmental coursework. The data used in this study did not use average district income. Instead, we used school-level rates of eligibility for FARMs as a proxy for lower income schools. However, previous research has found that districts with higher concentrations of poverty often yield more students needing developmental coursework classes (Rothstein, 2015). We found no relationship between the proportion of ELL students in a school or the mean weeks attended in a school and the need for math developmental coursework.

\section{Prevalence of the need for developmental education}

Although it was not a focus of the current paper, our reporting on the prevalence of the need for developmental education at community colleges in the state of Maryland warrants some discussion. More than half of students needed developmental coursework in at least one subject and a third needed developmental coursework in all three subjects. Estimates from previous studies have varied, ranging from about 40 to more than 70 percent needing developmental coursework (Bailey, Jeong, \& Cho, 2010; Chen, 2016; Radford \& Horn, 2012; Hodara, 2015). This variance is likely due to differences in methodology. Particularly, inclusion criteria, study length, data collection (administrative data vs. self-report), and the criteria for assessing the need for developmental coursework (Chen, 2016). As in previous literature, we found the most 
common need for developmental coursework in the current study was math, followed by English, then reading (Baily, Jeong, \& Cho, 2010; Chen, 2016). Although the exact percentages varied across previous studies, the subject-level rankings were consistent with our findings.

\section{Implications}

The majority of students who enter community colleges need developmental coursework before they can attempt credit bearing college level coursework in math or English (Chen, 2016). The community college system is distinct from the k-12 system, both structurally and fiscally. There are likely many historical and political explanations for the continued separation of these systems. Regardless of the administrative structures, community colleges are functionally dependent upon secondary schools to prepare the student body for college level coursework. As such, preventing the need for developmental coursework for community college students will not be resolved within institutional siloes and will most probably require some degree of intersystem collaboration. Community colleges tend to draw from a more regional population than four-year institutions, which fosters a more direct relationship between the local educational policies at the secondary and post-secondary level. This dynamic increases the opportunities for, and potential impact of, localized vertically integrated collaboration in both policy and practice.

For example, this study found that students who graduate high school in five years were less likely to need developmental coursework in math compared to four-year graduates. It is not clear how the efficacy of a fifth-year of high school compares, in terms of both academic preparation and cost, to college-level developmental coursework. It is however, worth considering that under certain conditions a fifth year of high school may be the preferable option. This is especially true when the costs in terms of financial aid eligibility of the student are considered. When developmental education is conducted in the post-secondary setting, much of 
the financial burden is borne by the student rather than the state or jurisdiction. This has important social and economic justice implications, especially when one considers that the need for developmental coursework is most common among student groups that are already economically and socially vulnerable (Chen, 2016).

As in previous studies, we found that students from traditionally underserved and vulnerable groups — women, Hispanic, special education, and FARMs eligible students — were more likely to need developmental coursework in math. There is extensive research documenting the relationship between membership in these subgroups and poor educational outcomes. It bears repeating however, that policy and practice innovations are needed to create a more equitable educational environment.

In the early years of school, female students often do well in math and science; however, as they enter adolescence researchers observe that female students begin to fall behind their male counterparts in both subjects (Petersen \& Hyde, 2017; Reilly, Neumann, \& Andrews, 2014). Some research has found that the implicit biases of teachers against females in math help perpetuate the stereotype that girls are not good in math (Nosek et al., 2009). Addressing this dynamic will likely require targeted interventions that challenge gender stereotypes among educators as well as students. For example, simultaneous educational campaigns that both increase girls' participation and performance in math while also combating the pervasive negative stereotypes about young women's math abilities may help to challenge prejudicial messaging and behaviors that underpin the increased risk for poor math outcomes among female students.

About half of Latino students who attend community college will enroll in non-credit bearing developmental coursework, prolonging their time to completing their educational goals 
(Mejia et al., 2016). In addition, just $24 \%$ of the Latino students that move on from developmental to a credit bearing math course will complete the for-credit course. Latino students are more likely than other student groups to be first generation college students, thus they may have limited access to social capital or support in navigating the challenges of college (Zhou \& Portes, 2012). Moreover, Latino students tend to attend resource-poor public schools with high concentrations of students living in poverty. The combined experiences of inequitable distribution of educational resources and highly trained educators coupled with exposure to adversarial attitudes and systemic bias poses a threat to the academic success of Latino students (Dondero \& Muller, 2012). Additional research and programming is needed to support improved engagement with students and caregivers from traditionally underserved student groups. This could include efforts to identify and remedy implicit biases present in current educational practices and teacher preparation programs.

The bulk of the postsecondary-focused research concerning students with a history of receiving special education services have focused on programing and interventions to increase access and enrollment. In contrast, there is little research examining course taking or the factors related to overall college success for students with disabilities (Griffin \& Papay, 2017). Developmental disability is an umbrella term describing a wide range of diagnosis both physical and intellectual. The needs of students with specific diagnoses (e.g., autism, dyslexia, hearing loss) are likely to require vastly different intervention strategies. Thus, it would seem appropriate for researchers to approach future studies on the topic with an equal measure of nuance.

\section{Limitations}

The findings of this study should be interpreted within the following limitations. First, the overall sample was limited to students attending publicly funded schools in a single state, 
potentially limiting the generalizability of the results. Our results generalize to other populations to the extent that students and school systems in other states are similar to the students and schools in Maryland. Second, there was no information pertaining to school selectivity at the high school or postsecondary levels, so we were unable to identify schools designed to serve "atrisk" youth or the degree to which high school selectivity may relate to the need for developmental coursework. Third, confounding variables that may be associated with the predictors in the model and need for developmental coursework may be missing from our models. For example, students with higher levels of behavioral problems may be more likely to need developmental coursework, which may confound the findings of the current study (Rumberger, 2011).

\section{Conclusion}

This study examined the student and high school level predictors of need for developmental math coursework in community colleges using statewide administrative data to follow students in 228 high schools through 24 community colleges. Female students, Hispanic students, students eligible for FARMs, and students who received special education services in high school were more likely to need developmental coursework in Math. Receiving ELL services and graduating from high school in the fifth-year functioned as protective factors linked to a reduced likelihood of needing developmental coursework in math. In addition, student-level academic performance in high school had a larger influence on the odds that a student would need developmental education than socio-demographic factors. In the current study, students who attended schools with more FARMs eligible students had higher odds of needing developmental coursework in math, whereas those who attended schools with a higher percentage of fifth-year graduates were less likely to need developmental coursework in math. 
These findings present opportunities for early identification and suggest possible targets for intervention intended to reduce the likelihood that high risk students will need developmental coursework when they arrive at community college. 


\section{References}

Ankeny, E. M., \& Lehmann, J. P. (2010). The transition lynchpin: The voices of individuals with disabilities who attended a community college transition program. Community College Journal of Research and Practice, 34(6), 477-496. doi: 10.1080/10668920701382773

Atchison, D., Baker, B., Boyle, A., Levin, J., \& Manshi, K. (2017). Exploring the Quality of School-Level Expenditure Data: Practices and Lessons Learned in Nine Sites. Retrieved from the U.S. Department of Education website: https://www2.ed.gov/rschstat/eval/titlei/quality-expenditure-data/report.pdf

Attewell, P., Lavin, D., Domina, T., \& Levey, T. (2006). New evidence on college remediation.

Bailey, T. R., Jaggars, S. S., \& Jenkins, D. (2015). Redesigning America's community colleges. Harvard University Press.

Bailey, T., Jeong, D. W., \& Cho, S. W. (2010). Referral, enrollment, and completion in developmental education sequences in community colleges. Economics of Education Review, 29, 255-270. doi: 10.1016/j.econedurev.2009.09.002

Barnett, E. A., \& Reddy, V. (2017). College placement strategies: Evolving considerations and practices. In K. L. McClarty, K. D. Mattern, \& M. N. Gaertner (Eds.), Preparing students for college and careers: Theory, measurement, and educational practice (1st ed.). New York, NY: Routledge.

Barnett, E. A., Chavarín, O., \& Griffin, S. (2018). Math Transition Courses in Context: Preparing Students for College Success. CCRC Research Brief. Community College Research Center, Teachers College, Columbia University. 
Barnett, E., Fay, M., Pheatt, L. E., \& Trimble, M. J. (2016). What We Know About Transition Courses. New York: Community College Research Center, Teachers College, Columbia University.

Barnett, E.A., Bergman, P., Kopko, E., Reddy, V., Belfield, C.R., \& Roy, S. (2018). Multiple measures placement using data analytics an implementation and early impacts report. The Center for the Analysis of Postsecondary Readiness and MDRC.

Berg, G. A. (2016). Low-income students and the perpetuation of inequality: Higher education in America. Routledge: New York, NY.

Bettinger, E. P., \& Long, B. T. (2009). Addressing the needs of underprepared students in higher education does college remediation work. Journal of Human Resources, 44(3), 736-771. doi: $\underline{10.3386 / \mathrm{w} 11325}$

Bremer, C. D., Center, B. A., Opsal, C. L., Medhanie, A., Jang, Y. J., \& Geise, A. C. (2013). Outcome trajectories of developmental students in community colleges. Community College Review, 41(2), 154-175. doi: 10.1177/0091552113484963

Buddenhagen, Brian J. (2014). Opportunity Gaps and Remediation: Can Academic Intensity in High School Level the Playing Field? (Doctoral Dissertation). Retrieved from Electronic Theses and Dissertations (https://digitalcommons.du.edu/etd/97)

Callahan, R., Wilkinson, L., \& Muller, C. (2010). Academic achievement and course taking among language minority youth in US schools: Effects of ESL placement. Educational Evaluation and Policy Analysis, 32(1), 84-117. https://doi.org/10.3102/0162373709359805 
Chen, X. (2016). Remedial coursetaking at U.S. public 2-and 4-year institutions: Scope, experiences, and outcomes (Report No. NCES 2016-405). Retrieved from National Center for Education Statistics website: http://nces.ed.gov/pubsearch

Clotfelter, C. T., Ladd, H. F., Muschkin, C., \& Vigdor, J. L. (2015). Developmental education in North Carolina community colleges. Educational Evaluation and Policy Analysis, 37(3), 354-375. doi:10.17732/jbit2015/6

Collins, M., \& Couturier, L. (2008). Achieving the dream: State policy changes for community colleges. New England Journal of Higher Education, 23(1), 14-15. https://doi.org/10.1002/cc.20154

Dai, J., Li, Z., \& Rocke, D. (2006). Hierarchical logistic regression modeling with SAS GLIMMIX. In Proceedings of the thirty-first annual SAS users group international conference. Cary, North Carolina: SAS Institute Inc.

Dondero, M., \& Muller, C. (2012). School stratification in new and established Latino destinations. Social Forces, 91(2), 477-502. doi: 10.1093/sf/sos127

Duckworth, A. L., \& Quinn, P. D. (2009). Development and validation of the Short Grit Scale (GRIT-S). Journal of Personality Assessment, 91(2), 166-174. https://doi.org/10.1080/00223890802634290

Else-Quest, N. M., Hyde, J. S., \& Linn, M. C. (2010). Cross-national patterns of gender differences in mathematics: A meta-analysis. Psychological Bulletin, 136, 103-121. doi: $\underline{10.1037 / \mathrm{a} 0018851}$

Engle, J., \& Tinto, V. (2008). Moving Beyond Access: College Success for Low-Income, FirstGeneration Students. Pell Institute for the Study of Opportunity in Higher Education. 
Flores, S. M., \& Drake, T. A. (2014). Does English language learner (ELL) identification predict college remediation designation?: A comparison by race and ethnicity, and ELL waiver status. The Review of Higher Education, 38(1), 1-36. doi: 10.1353/rhe.2014.0041

Folk, E. D., Yamamoto, K. K., \& Stodden, R. A. (2012). Implementing inclusion and collaborative teaming in a model program of postsecondary education for young adults with intellectual disabilities. Journal of Policy and Practice in Intellectual Disabilities, 9(4), 257-269. https://doi.org/10.1111/jppi.12007

Fuchs, D., \& Fuchs, L. S. (2006). Introduction to response to intervention: What, why, and how valid is it? Reading Research Quarterly, 4(1), 93-99. https://doi.org/10.1598/rrq.41.1.4

Gandara P., Alvarado E., Driscoll A., \& Orfield G. (2012). Building pathways to transfer: Community colleges that break the chain of failure for students of color. Retrieved from The Civil Rights Project website: https://www.civilrightsproject.ucla.edu/research/college-access/diversity/buildingpathways-to-transfer-community-colleges-that-break-the-chain-of-failure-for-students-of$\underline{\text { color }}$

Gandara, P. C., \& Contreras, F. (2009). The Latino education crisis: The consequences offailed social policies. Massachusetts: Harvard University Press.

Griffin, M. M., \& Papay, C. K. (2017). Supporting students with intellectual and developmental disabilities to attend college. Teaching Exceptional Children, 49(6), 411-419. doi: $\underline{10.1177 / 0040059917711695}$

Halbach, G. (2015). College and career - Are Maryland students ready? Annapolis, MD: Department of Legislative Services 
Hein, V., Smerdon, B., Sambolt, M. (2013). Predictors of postsecondary success. Washington, D.C.: American Institutes for Research.

Hodara, M. (2015). What predicts participation in developmental education among recent high school graduates at community college? Lessons from Oregon (Report No. REL 2015081). Retrieved from Institute of Education Sciences website: http://ies.ed.gov/ncee/edlabs

Horn, L. \& Berger, R. (2004). College Persistence on the Rise? Changes in 5-year Degree Completion and Postsecondary Persistence Rates between 1995 and 2000 (Report No. NCES 2005-156). Retrieved from National Center for Education Statistics website: https://nces.ed.gov/pubs2005/2005156.pdf

Horn, L., Peter, K., \& Rooney, K. (2002). Profiles of Undergraduates in US Postsecondary Education Institutions: 1999-2000. Education Statistics Quarterly, 4(3), 79-86. https://doi.org/10.1037/e492172006-011

Hox, J. (2002). Multi-Level Analysis. London: Lawrence Erlbaum Associates, Publishers.

Huang, F. L. (2016). Alternatives to Multilevel Modeling for the Analysis of Clustered Data. The Journal of Experimental Education, 84(1), 175-196. doi:

\section{$\underline{10.1080 / 00220973.2014 .952397}$}

Hurd, N. M., \& Sellers, R. M. (2013). Black adolescents' relationships with natural mentors: Associations with academic engagement via social and emotional development. Cultural Diversity and Ethnic Minority Psychology, 19(1), 76. https://doi.org/10.1037/a0031095

Hurd, N. M., \& Zimmerman, M. A. (2014). An analysis of natural mentoring relationship profiles and associations with mentees' mental health: Considering links via support from 
important others. American Journal of Community Psychology, 53(1-2), 25-36. https://doi.org/10.1007/s10464-013-9598-y

Hurd, N. M., Tan, J. S., \& Loeb, E. L. (2016). Natural mentoring relationships and the adjustment to college among underrepresented students. American journal of community psychology, 57(3-4), 330-341. https://doi.org/10.1002/ajcp.12059

Jimerson, S. R., \& Ferguson, P. (2007). A longitudinal study of grade retention: Academic and behavioral outcomes of retained students through adolescence. School Psychology Quarterly, 22(3), 314-339. https://doi.org/10.1037/1045-3830.22.3.314

Jimerson, S. R., Anderson, G. E., \& Whipple, A. D. (2002). Winning the battle and losing the war: Examining the relation between grade retention and dropping out of high school. Psychology in the Schools, 39(4), 441-457. https://doi.org/10.1002/pits.10046

Kane, T., Boatman, A., Kozakowski, W., Bennett, C., Hitch, R., \& Weisenfeld, D. (2018). Remedial math goes to high school: An evaluation of the Tennessee SAILS program (CEPR Policy Brief). Cambridge, MA: Harvard University, Center for Education Policy Research.

Kline, R. B. (2011). Principles and practice of structural equation modeling. New York: Guilford Press.

Lamdin, D. J. (1996). Evidence of student attendance as an independent variable in education production functions. The Journal of educational research, 89(3), 155-162. https://doi.org/10.1080/00220671.1996.9941321 
Lindberg, S. M., Hyde, J. S., Petersen, J. L., \& Linn, M. C. (2010). New trends in gender and mathematics performance: A meta-analysis. Psychological Bulletin, 136, 1123-1135. doi: $\underline{10.1037 / \mathrm{a} 0021276}$

Lucas, T., Henze, R., \& Donato, R. (1990). Promoting the success of Latino language-minority students: An exploratory study of six high schools. Harvard Educational Review, 60(3), 315-341. https://doi.org/10.17763/haer.60.3.0160105tt9kgkq51

Mamiseishvili, K., \& Koch, L. C. (2011). First-to-second-year persistence of students with disabilities in postsecondary institutions in the United States. Rehabilitation Counseling Bulletin, 54(2), 93-105. https://doi.org/10.1177/0034355210382580

Mamiseishvili, K., \& Koch, L. C. (2012). Students with disabilities at 2-year institutions in the United States: Factors related to success. Community College Review, 40(4), 320-339. doi: $\underline{10.1177 / 0091552112456281}$

Mejia, M. C., Rodriguez, O., \& Johnson, H. (2016). Preparing students for success in California's community colleges. Retrieved from Public Policy Institute of California website: http://www.ppic.org/main/publication.asp?i=1215

Melguizo, T., Bos, J., \& Prather, G. (2011). Is developmental education helping community college students persist? A critical review of the literature. American Behavioral Scientist, 55(2), 173-184. doi: $\underline{10.1177 / 0002764210381873}$

Neubert, D. A., \& Redd, V. A. (2008). Transition services for students with intellectual disabilities: A case study of a public school program on a community college campus. Exceptionality, 16(4), 220-234. https://doi.org/10.1080/09362830802412265 
Nosek, B. A., Smyth, F. L., Sriram, N., Lindner, N. M., Devos, T., Ayala, A., ... \& Kesebir, S. (2009). National differences in gender-science stereotypes predict national sex differences in science and math achievement. Proceedings of the National Academy of Sciences, 106(26), 10593-10597. doi: 10.31234/osf.io/sp8nc

Petersen, J. L., \& Hyde, J. S. (2017). Trajectories of self-perceived math ability, utility value and interest across middle school as predictors of high school math performance. Educational Psychology, 37(4), 438-456. doi: 10.1080/01443410.2015.1076765

Plotner, A. J., \& Marshall, K. J. (2015). Postsecondary education programs for students with an intellectual disability: Facilitators and barriers to implementation. Intellectual and developmental disabilities, 53(1), 58-69. https://doi.org/10.1352/1934-9556-53.1.58

Radford, A.W., \& Horn, L. (2012). Web Tables-An Overview of Classes Taken and Credits Earned by Beginning Postsecondary Students (Report No. NCES 2013-151REV). Retrieved from National Center for Education Statistics: https://nces.ed.gov/pubs2013/2013151rev.pdf

Reilly, D., Neumann, D. L., \& Andrews, G. (2015). Sex differences in mathematics and science achievement: A meta-analysis of National Assessment of Educational Progress assessments. Journal of Educational Psychology, 107(3), 645. doi: 10.1037/edu0000012

Rothstein, R. (2015). The racial achievement gap, segregated schools, and segregated neighborhoods: A constitutional insult. Race and Social Problems, 7(1), 21-30. doi:

\section{$10.1007 / \mathrm{s} 12552-014-9134-1$}

Rumberger, R. W. (2011). Dropping out: Why students drop out of high school and what can be done about it. Cambridge, MA: Harvard University Press. 
Scott-Clayton, J., \& Rodriguez, O. (2012). Development, discouragement, or diversion? New evidence on the effects of college remediation (Report No. w18328). Retrieved from the National Bureau of Economic Research website: http://www.nber.org/papers/w18328

Scott-Clayton, J., Crosta, P. M., \& Belfield, C. R. (2014). Improving the targeting of treatment: Evidence from college remediation. Educational Evaluation and Policy Analysis, 36(3), 371-393. https://doi.org/10.3102/0162373713517935

Studenmund, A. H. (2014). Using econometrics: A practical guide. Boston: Pearson.

Sugai, G., Lewis-Palmer, T, \& Hagan-Burke, S. (2000). Overview of the functional behavioral assessment process. Exceptionality, 8(3), 149-160

Thoma, C. A., Lakin, K. C., Carlson, D., Domzal, C., Austin, K., \& Boyd, K. (2011). Participation in postsecondary education for students with intellectual disabilities: A review of the literature 2001-2010. Journal of Postsecondary Education and Disability, 24(3), 175-191.

Ward, L., Siegel, M., \& Davenport, Z. (2012). First generation college students: Understanding and improving the experience from recruitment to commencement. John Wiley \& Sons, San Francisco, CA.

Williams, M. R., Tompkins, P., \& Rogers, B. (2018). High School Teachers' Perceptions of Developmental Education. Journal of Developmental Education, 41(2), No. 2.

Zhou, M., \& Portes, A. (2012). The new second generation: Segmented assimilation and its variants. In The New Immigration (pp. 99-116). Routledge: NY 
Table 1

Student-level Sample Characteristics $(N=18,814)$

\begin{tabular}{lrc}
\hline & $n$ & $\%$ \\
\hline Female $(n=18,809)$ & 9,860 & 52 \\
White $(n=18,814)$ & 9,368 & 50 \\
Black $(n=18,814)$ & 12,541 & 33 \\
Asian $(n=18,814)$ & 1,251 & 7 \\
Other Race $(n=18,814)$ & 1,922 & 10 \\
Hispanic $(n=18,814)$ & 2,379 & 13 \\
English Language Learner $(n=18,814)$ & 1,037 & 6 \\
FARMS Eligible $(n=18,814)$ & 7,771 & 41 \\
Special Education $(n=18,814)$ & 1,758 & 9 \\
GPA 3.0 or Above $(n=18,469)$ & 5,476 & 30 \\
Foreign Language Indicator* $(n=18,469)$ & 7,533 & 41 \\
Math Indicator* $(n=18,469)$ & 5,275 & 29 \\
Science Indicator* $(n=18,469)$ & 3,314 & 18 \\
Fifth-Year Graduate $(n=18,814)$ & 347 & 2 \\
\hline \hline
\end{tabular}

Weeks Attended $(\mathrm{n}=18,803)$

$34 \quad 4.658$

Note. "Indicates student took two or more classes in the subject with a grade or B or higher. 
Table 2

School-level Sample Characteristics $(n=228)$

\begin{tabular}{lcc}
\hline & Mean & SD \\
\hline \% White & 46 & 33.179 \\
\% FARMS & 50 & 27.538 \\
\% English Language Learner & 4 & 5.088 \\
\% Fifth-Year Graduate & 10 & 15.358 \\
\% GPA 3.0 or Above & 29 & 20.93 \\
\% Math Indicator & 26 & 15.159 \\
\% Foreign Language Indicator ${ }^{*}$ & 38 & 15.881 \\
\% Science Indicator & 16 & 14.568 \\
Mean Weeks Attended & 33 & 24.724 \\
School Size & 256 & 148.260 \\
\hline \hline & $f$ & $\%$ \\
\hline Regular High School & 192 & 84 \\
Vocational-Tech School & 14 & 6 \\
Alternative School & 12 & 6 \\
Charter School & 10 & 4 \\
\hline
\end{tabular}

Note. ${ }^{*}$ Indicates student took two or more classes in the subject with a grade or B or higher 


\section{Table 3}

Percentage, Distribution, and Subject level Overlap of Remedial Assessment Outcomes

\begin{tabular}{lrccc}
\hline & \multicolumn{2}{c}{ Total } & \multicolumn{2}{c}{$\begin{array}{c}\text { Assessed to } \\
\text { Need Remedial } \\
\end{array}$} \\
\cline { 2 - 5 }$(N=18,814)$ & \multicolumn{2}{c}{$(n=10,774)$} \\
\hline Any Remedial & 10,774 & 57 & - & - \\
Math & 9,925 & 52 & 9,925 & 92 \\
English & 5,315 & 28 & 5,315 & 49 \\
Reading & 4,738 & 25 & 4,738 & 44 \\
& & & & \\
Math only & - & - & 5,205 & 40 \\
Reading only & - & - & 254 & 2 \\
English only & - & - & 284 & 3 \\
$\quad$ English \& Reading & - & - & 311 & 3 \\
Math \& Reading & - & - & 849 & 8 \\
Math \& English & - & - & 1,396 & 13 \\
All three subjects & - & - & 3,324 & 31 \\
\hline
\end{tabular}


Results for the Multilevel Logit Model Fitted to Evaluate the Contributions of Student and School-level Factors on the Odds of Needing Math Remediation at Community College for Recent High School Graduates $(N=18,459)$

\begin{tabular}{|c|c|c|c|c|c|c|c|}
\hline & \multirow[b]{2}{*}{$\beta$} & \multirow[b]{2}{*}{$S E$} & \multirow[b]{2}{*}{$t$-score } & \multirow[b]{2}{*}{$p$} & \multirow[b]{2}{*}{$O R$} & \multicolumn{2}{|c|}{$95 \% \mathrm{CI}$} \\
\hline & & & & & & Lower & Upper \\
\hline \multicolumn{8}{|l|}{ Fixed Effects } \\
\hline Intercept & 1.090 & .335 & 3.26 & .001 & & & \\
\hline \multicolumn{8}{|l|}{ Student Characteristics } \\
\hline Female & .384 & .034 & 11.35 & $<.0001$ & 1.468 & 1.374 & 1.569 \\
\hline Black & .068 & .049 & 1.38 & .169 & 1.070 & .972 & 1.178 \\
\hline Asian & -.170 & .075 & -2.26 & .024 & .844 & .728 & .977 \\
\hline Other Race & .092 & .067 & 1.37 & .172 & 1.096 & .961 & 1.251 \\
\hline Hispanic & .247 & .064 & 3.88 & .000 & 1.281 & 1.130 & 1.451 \\
\hline English Language Learner & -.930 & .078 & -11.89 & $<.0001$ & .395 & .338 & .460 \\
\hline Free \& Reduced Meals & .083 & .039 & 2.11 & .035 & 1.086 & 1.006 & 1.172 \\
\hline Special Education & .225 & .057 & 3.91 & $<.0001$ & 1.252 & 1.118 & 1.401 \\
\hline GPA 3.0 or Above & -.490 & .047 & -10.45 & $<.0001$ & .612 & .559 & .671 \\
\hline Foreign Language Indicator* & -.266 & .039 & -6.86 & $<.0001$ & .767 & .711 & .827 \\
\hline Math Indicator ${ }^{*}$ & -.860 & .042 & -20.4 & $<.0001$ & .423 & .390 & .460 \\
\hline Science Indicator ${ }^{*}$ & -.541 & .051 & -10.56 & $<.0001$ & .582 & .527 & .644 \\
\hline Fifth-Year Graduate & -.410 & .125 & -3.27 & .001 & .664 & .519 & .848 \\
\hline Weeks Attended & .049 & .176 & 0.28 & .780 & 1.050 & .744 & 1.483 \\
\hline \multicolumn{8}{|l|}{ School Characteristics } \\
\hline$\%$ FARMS & .082 & .018 & 4.43 & $<.0001$ & 1.085 & 1.047 & 1.125 \\
\hline \% English Language Learner & -.061 & .060 & -1.02 & .309 & .941 & .836 & 1.058 \\
\hline$\%$ Fifth-Year Graduate & -.073 & .033 & -2.21 & .027 & .930 & .872 & .992 \\
\hline Mean Weeks Attended & -.011 & .176 & -0.06 & .951 & .989 & .701 & 1.396 \\
\hline \multicolumn{8}{|l|}{ Covariance Parameters } \\
\hline Intercept (School) & .041 & .010 & $4.0^{\dagger}$ & $<.0001$ & & & \\
\hline
\end{tabular}

Note. Dummy variables for jurisdictions were included in the model to account for the between-jurisdiction variance in the dependent variable. Estimates for these parameters are not reported; "Indicates student took two or more classes in the subject with a grade or B or higher; $\dagger=\mathrm{z}$-score. 